\title{
Pemikiran Hukum Waris Islam Maulana Syekh Muhammad Zainuddin Abdul Madjid
}

\author{
Zainal Arifin Munir \\ Fakultas Syariah Universitas Islam Negeri Mataram \\ Email: yanmu4all@yahoo.com
}

\begin{abstract}
Abstrak
Penelitian ini membahas pendapat hukum dan praktik hukum waris yang diajukan oleh Maulana Syaikh di kalangan masyarakat Sasak. Penelitian ini berfokus pada konstruksi pendapat hukum waris oleh Maulana Syaikh, dampak pendapat hukum waris oleh Maulana Syaikh untuk masyarakat Sasak, dan kontribusi pendapat hukum waris oleh Maulana Syaikh untuk pengembangan hukum Islam. Ini adalah penelitian perpustakaan. Namun, penelitian ini juga membutuhkan data lapangan sosiologis untuk merekonstruksi pendapat hukum warisan oleh Maulana Syaikh. Pengumpulan data dilakukan melalui dokumentasi, wawancara, dan observasi. Penelitian ini mengungkapkan bahwa komunitas Sasak memiliki tiga pola distribusi warisan: a) Jika seseorang meninggal, ahli waris yang berhak atas semua kekayaannya adalah putra tertua di keluarganya. Putra tertua yang menerima kekayaan dari orang tua bertanggung jawab atas semua kebutuhan adik dan keluarganya; b) Jika seseorang meninggal, anak laki-lakinya berhak atas tanah dan rumah, sedangkan anak perempuannya berhak atas segala perabot yang ditemukan di rumah seperti peralatan dapur dan barang pecah belah; c) Distribusi warisan dilakukan sebelum seseorang meninggal dalam bentuk surat wasiat atau hibah. Ini sering tidak menggunakan hukum Islam sebagai referensi. Bahkan, kehadiran Maulana Syaikh dengan pendapat hukumnya tentang pewarisan berdasarkan hukum Islam perlahan menggantikan praktik hukum adat yang dampaknya dapat digambarkan sebagai berikut: a) Distribusi warisan dilakukan sesuai dengan hukum waris yang ditulis dalam sebuah buku tuhfat alampenaniyyah; b) Distribusi warisan dilakukan sesuai dengan hukum waris, tetapi warisan tersebut didistribusikan ketika seseorang masih hidup; c) Sebagian dari kekayaan dibuat sebagai hibah, sedangkan sisanya didistribusikan sesuai dengan hukum Islam tentang warisan; d) Distribusi warisan dilakukan dengan menggunakan metode hibah sesuai dengan kesepakatan di antara anggota keluarga; e) Distribusi warisan dilakukan dengan menggunakan surat wasiat. Secara metodologis, pendapat Maulana Syaikh dan praktik pewarisan mengacu pada pola bayani, tetapi dalam praktiknya, masyarakat Sasak cenderung menggunakan pola ijtihad maqasidi.
\end{abstract}

Kata kunci: Hukum Waris Adat Sasak, Hukum Waris Islam, Maslahah, Al-Maqashid Al-Syari'ah 


\title{
Legal Thinking of Islamic Inheritance Maulana Shaykh Muhammad Zainuddin Abdul Madjid
}

\author{
H. Zainal Arifin Munir \\ Syariah Faculty, Mataram State Islamic University
}

\begin{abstract}
Abstrak
This research discusses the legal opinion and practice of inheritance law proposed by Maulana Syaikh among Sasak community. This research focuses on the construction of the legal opinion of inheritance by Maulana Syaikh, the impacts of the legal opinion of inheritance by Maulana Syaikh for Sasak community, and the contribution of the legal opinion of inheritance by Maulana Syaikh for the development of Islamic laws. This was a library research. However, this research also needed sociological field data in order to reconstruct the legal opinion of inheritance by Maulana Syaikh. The data collection was done through documentation, interview, and observation. This research revealed that Sasak community has three patterns of distributing inheritance: a) If a person dies, the beneficiary who is entitled to all his wealth is the oldest son in his family. The oldest son who receives the wealth from the parents is responsible for all the needs of his younger siblings and families; b) If a person dies, his sons are entitled to lands and houses, while his daughters are entitled to any furnitures that are found in the house such as kitchen utensils and glassware; c) The distribution of inheritance is done before a person dies in the form of a will or grant. This often does not use Islamic laws as a reference. In fact, the presence of Maulana Syaikh with his legal opinion on inheritance based on Islamic law slowly replaced the practice of customary law whose impacts can be described as follows: a) The distribution of inheritance is done in accordance with the inheritance law written in a book tuhfat alampenaniyyah; b) The distribution of inheritance is done in accordance with the inheritance law, but the inheritance is distributed when a person is still alive; c) A part of the wealth is made as a grant, while the remaining is distributed in accordance with Islamic law on inheritance; d) Thedistribution of inheritance is done using a grant method in accordance with agreement among the family members; e) The distribution of inheritance is done using a will. Methodologically, Maulana Syaikh"s opinion and practice of inheritance refer to bayani pattern, but in practice, Sasak community tends to use ijtihad maqasidi pattern.
\end{abstract}

Keywords: Sasak Customary Inheritance Law, Islamic Inheritance Law, Maslahah, Al-Maqashid Al-Syari'ah 


\section{PENDAHULUAN}

Fikih adalah hasil pemahaman seseorang yang diambil dari dalil yang terperinci (al-Qur'ān dan hadìs) yang dijadikan sebagai barometer praktis keseharian dalam masyarakat. Dengan demikian, fikih terkadang juga juga disebut juga dengan hukum Islam. Hukum Islam Indonesia adalah 'kumpulan' dari berbagai ragam pendapat ulama masa lampau (yang tertuang dalam referensi kitab fikih) yang kemudian diramu menjadi acuan praktis masyarakat Indonesia dalam bidang hukum yang terkait. Hukum Islam Indonesia adalah hasil ijtihäd masyarakat Indonesia untuk merealisasikan hukum Islam dalam konteks ke-Indonesia-an. ${ }^{1}$ Dalam konteks ini fikih (hukum Islam) harus dipandang sebagai sesuatu yang dinamis dan terbuka yang terikat oleh ranah historis kemanusiaan, dan selalu terkungkung oleh ruang dan waktu.

Realitas di atas menunjukkan bahwa hukum Islam berkembang didasarkan atas realitas-empiris perkembangan masyarakat. Seiring dengan di atas, al-Syahrastani menuliskan al-nușuș mutanāhiyah wa al-wāqi'ah gairu mutanāhiyah (al-Qur'ānhadìs sudah habis diturunkan, namun peristiwa hukum tidak pernah ada habisnya). Hal ini juga menunjukkan bahwa pada hakekatnya upaya ijtihād itu mutlak dibutuhkan dalam kerangka menjawab ke-

1 Beberapa materi fikih yang menjadi materi hukum positif di Indonesia adalah di antaranya hukum tentang pernikahan (UU. N0. 1 tahun 1974 tentang Perkawinan), hukum waris (Intruksi Presiden No. 1 tahun 1991 tentang Kompilasi Hukum Islam), hukum haji (UU. No. 17 tahun 1999), hukum zakat UU. No. 38 tahun 1999 tentang Zakat), hukum wakaf (UU. No. 41 tahun 2004), hukum muamalat (UU. No. 21 tahun 2008 tentang Perbankan Syariah), dan lain-lain.Sebagai ilmu pengetahuan, substansinya hukum Islam mengikuti aturan yang berlaku dalam ilmu pengetahuan. Berbeda halnya hukum Islam sebagai acuan praktis amaliah dalam hidup keseharian yang terikat dalam norma dan dogma. Oleh karena hukum Islam itu sebagai ilmu pengetahuan, maka kebenaran yang ada dalam pemikiran hukum Islam adalah kebenaran yang bersifat relative-nisbi. Hal ini juga diakomodasi dalam kaedah ușüliyyahyang berbunyi al-ijtihād lā yuzālu bi al-ijtihād(hasil ijtihādseseorang tidak dapat dibatalkan oleh ijtihädorang lain). Ijtihädsebagai produk dari pemikiran hukum Islam didasarkan pada hipotesa yang siap diuji oleh kebenaran lain melali teas dan inquiry yang lebih mendalam pada bidang dan tema kajian yang sama. Muhammad ibn Ali al-Syaukani, Irsyad al-Fuhul ila tahqiq al-haq min 'Ilm al-Ușul, (Beirut: Daral-Fikr tth), hlm. 251. Ibn 'umar al-Baidawi, Minhạj al-Ușul ila 'Ilm al-Ușul (Beirut: Muassasah al-Risalah, tt.), hlm. 124. Al-Buti mengomentari definisi yang dikemukan al-Baidawi di atas, beliau membedakan antara ijtihāddalam arti luas dan arti khusus, yakni seluruh upaya mengerahkan tenaga untuk menghasilkan sesuatu yang ingin dicapainya. Lihat, Muhammad Sa'id Ramadan al-Buti, Hiwar Haula Musykilat Hadariyyah, (Damaskus: Daral-Farabi, 2005), hlm. 194. Abul Madjid as-Syarafi, IjtihādKolektif, terjemahan Syamsuddin TU, (Jakarta: Pustaka al-Kautsar 2002) hlm. 10. 
mungkinann terjadinya kekosongan hukum dalam masyarakat. Hallaq menuliskan bahwa berkembangnya hukum Islam pada awal imam mazhab(a immah Al-mażāhib) adalah bagian dari kreatifitas ulama salaf dalam mendialogkan teks naș dengan realitas. ${ }^{2}$ Pada sisi lain, pengembangan metodologi hukum (ilmu ushul fikih) juga semakin dikuatkan dengan hadirnya teori hukum yang dikembangkan oleh Imam al-Haramain al-Juwayni yang dilanjutkan oleh Imam Abu Hamid al-Gazali tentang mabādi' al-khams yang kemudian disempurnakan oleh Abu Ishaq Ibrahi dengan konsep maqashid al-syari'ah. Hari ini, banyak akademisi yang mencipta teori baru dalam bidang studi keislaman yang didasarkan pada kerangka berpikir maqashid.

Pada dasarnya, teori Al-maqashid ini adalah pengembangan dari konsep mașlahah Imam Anas ibn Malik, yang secara konsisten mendialogkan idealisme teks dan realitas empiris (maqashid al-syari' wa maqashid al-'ibād). Pertarungan hukum Islam hari ini adalah mencakup dua hal, yaitu pertama, keterbatasan teks naș dan realitas perkembangan hidup yang terus berkembang. Kedua, karena adanya perubahan yang ada dalam masyarakat yang terus berkembang idealisme teks kemudian dipertanyakan. ${ }^{3}$ Bukan meragukan wahyu yang diturunkan, namun lebih pada substansi keadilan yang semestinya ada dalam setiap diktum hukum.

Salah satu masalah hukum yang hari ini 'digugat' adalah masalah hukum waris Islam yang oleh sebagian orang dianggap tidak adil. Munawir Sadzali misalnya, dengan latar belakang kehidupan masyarakat Solo menggugat hukum waris Islam dengan menggunakan teori maslahat sebagai basis analisisnya. Demikian juga Syahrur yang menawarkan teori batas dalam memecahkan masalah pembagian waris Islam. ${ }^{4}$ Pergeseran pemikiran hukum waris Islam ini juga dibarengi dengan pergeseran konsep gender (relasi laki-perempuan) dalam masyarakat.

Pada hakekatnya, 'perseteruan' hukum waris Islam dengan sistem hukum lainnya (khususnya hukum adat) sebenarnya sudah lama terjadi.

2 Wael B. Hallaq, Authority, Continuity, and Change in Islamic Law, (Cambridge: Cambridge University Press, 2004), hlm. 174-213.

3 Muh.Salahuddin, Fatwa Ekonomi DSN-MUI dalam Sistem Maqashid al-Syari'ah, (Mataram, LP2M UIN Mataram, 2017), hlm. 5

4 Muhammad Syahrur, Al-Kitāb wa al-Qur'ān Qirā'ah Mu'asirah, (Damaskus: al-Ahab li al-Ṭiba'ah li al-Nasyr wa al-Tauzi', 1992). 
Dalam masyarakat Sasak (pulau Lombok) misalnya, sistem hukum waris adat amat sangat bertentangan dengan sistem hukum waris Islam. Pada sisi lain, masyarakat Sasak adalah masyarakat yang fanatik terhadap ajaran Islam. Dalam realitas seperti inilah ijtihād itu dibutuhkan. Tentunya, ijtihād itu dilakukan oleh orang yang secara keilmuan atau akademik mampu untuk melakukannya.Dalam konteks masyarakat Sasak, banyak ulama dengan berbagai ragam karya dan corak pemikiran fikih. Fikih masyarakat (ulama) Sasak ini adalah hasil dari dialog intelektual ulama dengan teks naș dan hasil refleksi mereka dengan realitas masyarakat Sasak. Salah satu ulama yang concern dengan pemikiran keislaman di Pulau Lombok adalah Maulana Syaikh TGKH. Zainuddin Abdul Madjid. Pemikiran beliau tertuang dalam banyak kitab, dan oleh sebagian besar masyarakat Sasak beliau dijadikan sebagai 'referensi hidup' dalam menjalankan aktivitas keseharian, dan lebih khusus dalam beragama. Dalam ertikel ini penulis tertarik untuk menelusuri lebih dalam tentang pemikiran beliau dalam bidang hukum waris Islam dan aplikasinya dalam masyarakat Sasak. Penelitian ini juga akan menelisik lebih jauh lagi terkait dengan pengaruh pemikiran beliau dan aplikasi pembagian waris oleh beliau bagi masyarakat Sasak.

Ada beberapa alasan mengapa Maulana Syaikh TGKH. Muhammad Zainuddin Abdul Madjid yang dijadikan sebagai tokoh sentral dalam penelitian ini, yaitu sebagai berikut:

1. Maulana Syaikh TGKH. Muhammad Zainuddin Abdul Madjid adalah ulama yang hingga hari ini menjadi referensi bagi masyarakat Sasak dalam aktivitas keberagamaan mereka.

2. Maulana Syaikh TGKH. Muhammad Zainuddin Abdul Madjid adalah ulama produktif yang mewariskan banyak karya tertulis bagi generasi masyarakat Sasak selanjutnya.

3. Maulana Syaikh TGKH. Muhammad Zainuddin Abdul Madjid mendirikan lembaga pendidikan Islam untuk mewarisi keilmuan beliau kepada masyarakat Sasak, dan oleh murid dan pengikut beliau dikuatkan lagi dengan mendirikan lembaga pendidikan yang sama. Hal ini semakin mengukuhkan beliau sebagai panutan dalam fikih praktis masyarakat. 
Dengan alasan di atas, tentunya pemikiran beliau dalam bidang hukum waris Islam vis avis hukum waris adat Sasak menjadi suatu kajian sosisologi hokum Islam yang bagi penulis menarik untuk dikaji. Pemikiran hukum waris Islam Maulana Syaikh Muhammad Zainuddin Abdul Madjid dianalisis dengan metodologi hukum Islam yang tertuang dalam al-kutub al-turāis dan teori lain yang terkait dengan itu, khususnya teori maqashid al-syari'ah.

\section{HASIL PENELITIAN DAN PEMBAHASAN}

\section{Pemikiran Hukum Waris Maulana Syekh Zainuddin}

Maulana Syekh dikenal sebagai tokoh yang cerdas dalam bidang fikih, sastra, ilmu al-Qur'an dan tasawuf.Selain sebagai ulama, beliau juga dikenal sebagai tokoh pergerakan dan perubahan dalam masyarakat Lombok.Kecerdasan beliau tampak dari prestasi dan karya akademik yang ditulisnya dalam 3 bahasa (Arab, Melayu, dan Sasak).Dalam bidang hokum kewarisan Islam, ada dua karya beliau dan ditulis dengan bahasa sastra Arab yang sangat tinggi.Yang menarik lagi bahwa karya beliau dalam bidang kewarisan ini ditulis dalam satu malam. ${ }^{5}$ Karya fikih waris Maulana Syekh ditulis tahun 1969, di saat kegelisahan pribadi beliau merespon realitas social saat itu yang penuh dengan kekacauan dan ketidakpastian.

Metodologi hokum yang digunakan beliau dalam penulisan hokum waris ini adalah metode deduktif (bayāni). Hal tersebut tampak dalam tulisan beliau yang menyatakan bahwa والأخذ من كتاب رب الناس* والسنة الإجماع لا القياس (dan hendaknya berpedoman pada kitab, sunnah dan ijmā' dengan mengabaikan qiyās).Metodologi sebagaimana di atas didasarkan pada realita bahwa hukum waris (secara keseluruhan) adalah sesuatu yang langsung diturunkan/ ditetapkan oleh Allah, baik yang penerima dan jumlah (hak) yang harus diterimanya.Oleh karena itu beliau membagi hukum Islam itu menjadi ilmu syariah dan ilmu syara'. Ilmu syariah itu berasal dari Allah langsung yang berupa perintah dan larangan yang tertulis dalam al-Qur'ān dan hadìis. Sedangkan ilmu syara' adalah pemikiran hukum (hasil ijtihād)

5 Wawancara dengan Umi Raehanun, anak Maulana Syekh Zaenuddin Abdul Madjid. 
manusia yang eksistensinya dibolehkan oleh syariah. ${ }^{6}$

Dari pola deduktif-bayāni yang digunakan oleh Maulana Syekh, sebenarnya tidak ada sesuatu yang baru dalam tulisan beliau.Hanya saja, yang perlu diapresiasi adalah adalah kegelisahan intelektual pribadi penulis dan realitas social yang melingkupi tulisan beliau.Pertama, karya beliau dihajatkan agar pengetahuan hokum waris Islam tidak hilang dan dilupakan oleh masyarakat Sasak. Kedua, pengetahuan hokum waris Islam untuk masyarakat Sasak saat itu adalah sesuatu yang baru dan perlu diperkenalkan.Ketiga, sebelum berbicara ilmu syara' sebaiknya masyarakat harus mengetahui terlebih dulu ilmu syari'ah. Dalam konteks kewarisan ini, Maulana Syekh mengajarkan substansi agama 'dahulukan kehendak Allah, baru kemudian libatkan akal manusia'.Pokok pemikiran hokum kewarisan Maulana Syekh dalam karya hokum waris dapat diuraikan sebagai berikut :

a. Ontologi hokum waris Islam didefinisikan sebagai ilmu tentang hukum syara' yang bersifat praktis yang khusus terkait dengan harta

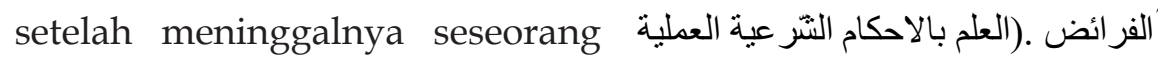
7 المختص تعلقها بالمال بعد موت مالكه تحقيقا اوتقدبر العزئ

b. Hukum mempelajari ilmu waris adalah wajib ‘ain dan wajib kifāyah. Beliau menuliskan وحكمه هو الوجوب العين*أو الكفائي بغير مين Maulana Syekh menetapkan bahwa tujuan mempelajari ilmu faraid adalah untuk menyelesaikan masalah harta peninggalan sesuai dengan ketentuan agama, dan jangan ada pihak yang dirugikan dalam pembagian warisan.

c. Sistematika penulisan karya Maulana Syekh Zaenuddin diawali dengan uraian ketentuan al-Quran dan hadis tentang kewarisan. Pemikiran hokum waris beliau diawali dengan kutipan QS. al-Nisā': $7,8,9,10,11,12$, dan 13. Selain ayat al-Qur'ān, beliau juga menyandarkan pemikiran hukum waris pada beberapa hadis terkait dengan hokum waris.

6 Muhammad Zainuddin Abdul Madjid, Al-Tuhfah al-Anfananiyyah Syarh al-Nahdlat al-Zainiyah, cet. I (Pancor: Pondok Pesantren Darun Nahdlatain, 1978), hlm. 13.

7 Muhammad Zainuddin Abdul Madjid, Tuhfah Al-Anfanāniyyah, hlm.14-15

$8 \quad$ Ibid., hlm.20 
d. Berangkat dari kutipan nas di atas, Maulana Syekh Zaenuddin mengurai substansi hokum waris sebagai berikut :

$$
\text { أركانه ثلاثة بلا شطط*مورث ووارث حق سقط }
$$

"Rukun waris itu ada tiga hal yang tidak bisa lebih dan tidak bisa kurang yaitu orang yang meninggal, ahli waris dan hak kebendaan yang ditinggalkan". ${ }^{9}$

Maulana Syaikh Muhammad Zainuddin Abdul Madjid merincikan ahli waris dalam syair berikut ini:

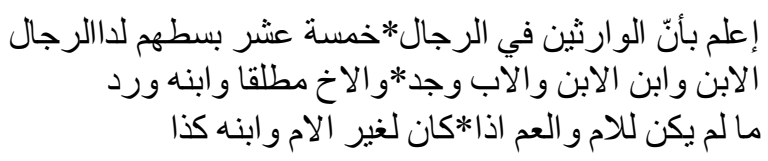

"Ketahuilah sesungguhnya ahli waris dari pihak laki-laki kalau dikumpulkan akan berjumlah lima belas orang yaitu anak laki-laki, cucu laki-laki, bapak/ayah, kakek, saudara sekandung, anak saudara, saudara seibu dan seayah, paman sekandung, paman sebapak, paman seibu, suami, orang yang memerdekakan hamba"10

Adapun ahli waris dari pihak perempuan menurut Maulana Syaikh Zainuddin adalah

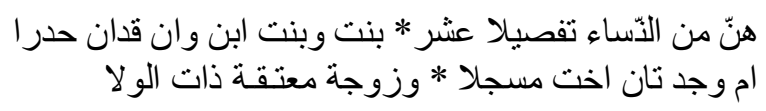

"Mereka dari pihak ahli waris perempuan sebanyak sepuluh orang yang dijelaskan secara terperinci yaitu: anak perempuan, cucu perempuan, ibu, nenek dari pihak ibu, dan nenek dari pihak bapak, saudari sekandung, saudari sebapak saja, saudari seibu saja, dan perempuan yang telah memerdekakan

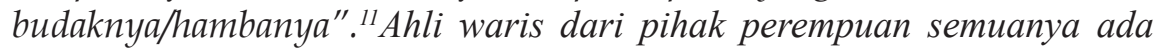
berkumpul maka ahli waris yang dapat ada lima yaitu: anak perempuan,

9 Zainuddin Abdul Madjid, Nahdlat Al-Zainiyyah,...,hlm.23

10 Muhammad Zainuddin Abdul Madjid, Tuhfah Al-Anfanāniyyah,...,,hlm.29-31

11 Ibid., hlm.33-34. 
cucu perempuan, ibu, isteri dan saudari sekandung. ${ }^{12}$ Jika semua ahli waris dari pihak laki-laki dan pihak perempuan berkumpul semua atau bercampur maka yang berhak menjadi ahli waris adalah ayah, ibu, anak laki-laki, anak perempuan dan salah satu dari suami/isteri. ${ }^{13}$ Beliau menuliskan sebagai berikut:

$$
\text { ولـو * اختلط الكل لخمسة حبو الاب و الام و ابن و العين * و البنت نمّ احد الزّوجين }
$$

"Apabila semua ahli waris dari pihak laki-laki dan perempuan berkumpul semua atau bercampur gaur maka yang berhak menjadi ahli waris adalah ayah, ibu, anak laki-laki, anak perempuan dan salah satu darisuami/isteri. ${ }^{14}$

Ada tiga sebab seseorang bisa saling waris mewarisi, Maulana Syekh Zainuddin menuliskan

$$
\text { أسبابه ثلاثة قرابة * ثم النكاح و و لا العتا قه }
$$

"Adapun sebab-sebab saling waris mewarisi yaitu melalui hubungan darah, melalui hubungan perkawinan dan melalui sebab wala' atau memerdekakan hamba". ${ }^{15}$

Furū syar'i terbagi dalam enam kelompok, Mualana Syekh menuliskan :

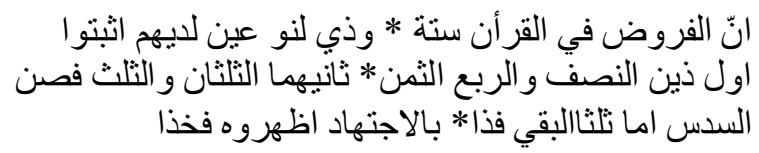

"Sesungguhnya bagian-bagian yang yang telah ditentukan didalam alQur'ān itu ada enam bagian yaitu setengah, seperempat, seperdelapan, dua pertiga, sepertiga dan seperenam. Adapun bagian dari sepertiga baqi merupakan ijtihādsemata".

12 Ibid., hlm.36-37.

13 Ibid., hlm.37-38.

14 Ibid.

15 Ibid.,hlm.26 
Bagian anak perempuan النصف للبنت اذا ماانفردت * والثلثان الفرض ان تعددث (Anak perempuan mendapat setengah dari harta ditinggalkan jika sendirian)". Anak perempuan mendapat 2/3 dari harta yang ditinggalkan dengan syarat jika anak perempuan tersebut lebih dari satu orang dan tidak ada saudara laki-laki النصف للبنت اذا مانفردت * والثلثان الفرض ان تعددت (anak perempuan mendapat 2/3 dari harta peninggalan jika anak tersebut lebih dari seorang". Anak perempuan mendapat 'așobah jika anak perempuan tersebut bersama dengan saudara laki-laki. تعصيبها بالابن و هو للذكر * مثل نصيب الانثيين قد ظهر. puan menjadi 'asobahjika bersama dengan anak laki-laki dan anak laki-laki dua kali bagian anak perempuan".

Bagian cucu perempuan dituliskan sebagai berikut :

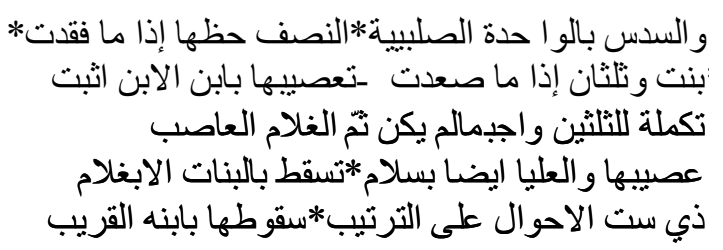

Cucu perempuan tersebut mendapat 'așobah dengan ketentuan jika cucu perempuan tersebut bersama dengan cucu laki-laki. ${ }^{16} \mathrm{Cucu}$ perempuan tersebut mendapat $1 / 6$ dari harta yang di tinggalkan oleh si mayit dengan ketentuan jika cucu perempuan tersebut bersama-sama dengan anak perempuan di mayit. ${ }^{17} \mathrm{Cucu}$ perempuan tersebut suqut tidak mendapat apa-apa\} dari harta yang di tinggalkan si mayit dengan ketentuan jika si mayit meninggalkan dua orang anak perempuan atau lebih. ${ }^{18} \mathrm{Cucu}$ perempuan tersebut suqut (tidak mendapat apa-apa) dari harta yang di tinggalkan si mayit dengan ketentuan jika si mayit meninggalkan anak laki-laki. ${ }^{19}$

16 Muhammad Zainuddin Abdul Madjid, Tuhfah Al-Anfanāniyyah..., hlm.62

17 Ibid., hlm.63

18 Ibid.,hlm.55-56

19 Ibid.,hlm.67 
Bagian Saudari Sekandung menurut Maulana Syaikh Muhammad Zainuddin Abdul Madjid ada lima ketentuan sebagai berikut:

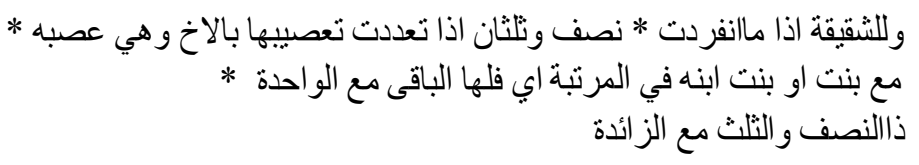

'Saudari sekandung mendapat 1/2 dari harta yang ditinggalkan dengan syarat jika saudari kandung tersebut sendirian dan si mayit tidak meninggalkan anak laki-laki maupun anak perempuan dan cucu baik cucu laki-laki maupun cucu perempuan'.

Bagian saudari sebapak Maulana Syaikh Zainuddin menuliskan sebagai berikut:

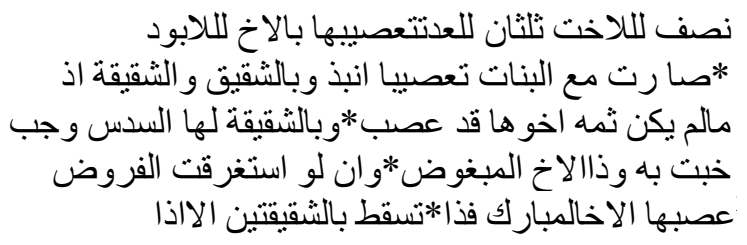

Maulana Syaikh Muhammad Zainuddin Abdul Madjid menulsikan bahwa saudari seibu dalam mewarisi ada tiga ketentuan bagian sebagai berikut:

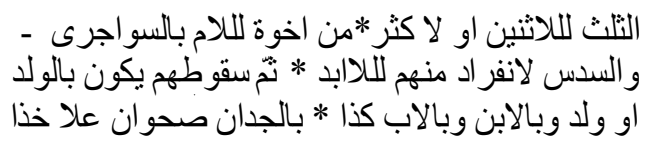

'Saudari seibu saja mendapat $1 / 3$ dari harta yang ditinggalkan dengan syarat jika saudari seibu tersebut dua orang atau lebih dan si mayit tidak meninggalkan anak baik anak laki-laki maupun anak perempuan dan cucu baik cucu laki-laki maupun сиси perempuan terus bawah, bapak, kakek dan terus ke atas.'Saudari seibu saja mendapat 1/6 dari harta yang ditinggalkan dengan syarat jika saudari seibu tersebut sendirian dan si mayit tidak meninggalkan anak baik anak laki-laki maupun anak perempuan dan cucu baik cucu laki-laki maupun cucu perempuan terus bawah, bapak, kakek dan terus ke atas. Saudari seibu suqūt (tidak mendapat apa-apa) dari harta yang 
ditinggalkan dengan syarat jika si mayit meninggalkan anak baik anak laki-laki maupun anak perempuan dan cucu baik cucu laki-laki maupun cucu perempuan terus bawah, bapak, kakek dan terus ke atas.

Bagian ibu dalam karya Maulana Syaikh Muhammad Zainuddin Abdul Madjid bahwa ibu dalam mewarisi ada tiga

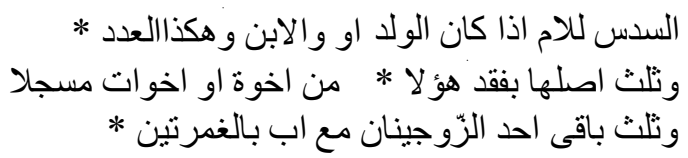

'Ibu mendapat $1 / 6$ dari harta yang ditinggalkan dengan syarat jika si mayit meninggalkan anak laki-laki maupun perempuan.Ibu mendapat 1/3dari harta yang ditinggalkan dengan syarat jika si mayit meninggalkan anak baik laki-laki maupun anak perempuan.Ibu mendapat 1/3 bāqi dari harta yang ditinggalkan denagn ketentuan jika si mayit tidak meninggalkan anak laki-laki maupun anak perempuan tersebut setelah bagian salah satu dari suami atau istri diberikan'. ${ }^{20}$

Bagian warisan untuk nenek, Maulana Syaikh Muhammad Zainuddin Abdul Madjid menuliskan sebagai berikut:

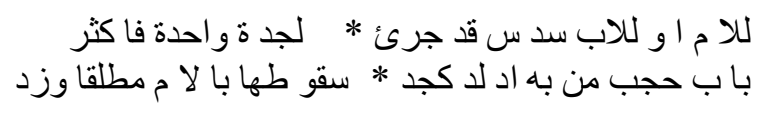

'Nenek mendapat 1/6 dari harta yang ditinggalkan dengan syarat jika si mayit tidak meninggalkan ibu dan bapak.Nenek menjadi suqūtt(tidak mendapat apa-apa) dari harta yang ditinggalkan denga syarat jika si mayit meninggalkan ibu dan bapak'. ${ }^{21}$

Bagian istri dituliskan oleh Maulana Syaikh Muhammad Zainuddin Abdul Madjid dalam syair berikut: 


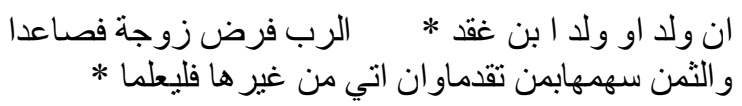

"Istri mendapat 1/4 dari harta yang ditinggalkan, dengan ketentuan apabila si mayit (suami) tidak meninggalkan anak baik anak laki-laki maupun anak perempuan". ${ }^{22}$ Adapun pandangan Maulana Syaikh dalam ulasannya tentang ketentuan bagian suami sebagai berikut:

$$
\text { النصف للزوج لدا عقد الولد * او ولد الابن وان ناى ورد }
$$

'Suami mendapat 1/2 dari harta yang ditinggalkan istri, dengan ketentuan apabila si mayit (istri) tidak meninggalkan anak baik anak laki-laki maupun anak perempuan'.Suami mendapat 1/4 dari harta yang ditinggalkan istri, dengan ketentuan apabila si mayit (istri) meninggalkan anak laki-laki maupun perempuan.

Bagian kakek menurut Maulana Syaikh Zainuddin Abdul Madjid adalah 1/6 dari harta yang ditinggalkan, dengan ketentuan apabila si mayit tidak meninggalkan ayah dan anak laki-laki.Kakek mendapat 1/ 6 ditambah dengan 'așobahdari harta yang tinggalkan, denga ketentuan apabila si mayit tidak meninggalkan ayah dan hanya meninggalkan anak perempaun. Kakek mendapat 'așobah khusus dengan ketentuan apabila si mayit tidak meninggalkan ayah, anak laki-laki dan anak perempuan, cucu laki-laki maupun cucu perempuan dan terus ke bawah. Kakek suqūt (tidak mendapat apa-apa) dari harta peninggalan karena si mayit meninggalkan ahli waris yaitu ayah.

Dalam membahas hijāb danmahjūb Maulana Syaikh Zainuddin menulis sebagai berikut:

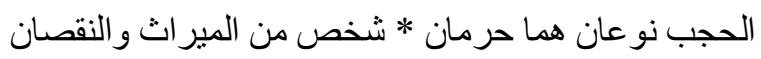

Ahli waris yang menjadi mahjūb karena adanya hijābhirmān adalah sebagai berikut: 1). Kakek mahjūb oleh bapak, 2). Nenek garis ibu

22 Ibid., hlm.91 
mahjub oleh ibu, 3). Nenek garis bapak mahjūb oleh bapak, 4). Cucu laki-laki mahjūboleh anak laki-laki, 5). Cucu perempuan mahjūb oleh anak laki-laki dan oleh anak perempuan lebih dari seorang (jika tidak bersama cucu laki-laki ).

Dengan hadirnya kitab Tuhfah al-zainiyyah dan TuhfahAlAnfanāniyyahkarya Maulana Syaikh Zainuddin Abdul Madjid (pada zaman itu) memberikan pengetahuan baru yang terkait dengan ilmu waris Islam. Dengan hadirnya karya beliau ini juga memudahkan masyarakat untuk memahami hukum waris Islam karena disampaikan dalam gaya bahasa yang ringan dan penjelasan yang terang. ${ }^{23} \mathrm{Kala}$ itu, dan bahkan hingga hari ini, banyak individu dalam masyarakat Lombok yang berselisih tentang pembagian warisan.Oleh karena adanya perselisihan yang kerapkali muncul itu, Maulana Syaikh Zainuddin Abdul Madjid menyelesaikan tulisan tentang hukum waris ini.Sebelum hadirnya karya beliau, beliau juga menyampaikan kajian tentang hukum waris di berbagai majlis ilmu.Dan dalam beberapa kasus, beliau turun sendiri dalam menyelesaikan sengketa waris dalam masyarakat dengan menggunakan hukum waris Islam.Terkadang apa yang beliau tulis seringkali beliau tinggalkan, karena realitas masyarakat yang secara psikis belum sanggup menerima hokum waris Islam.

\section{Praksis Pembagian Warisan Maulana Syekh}

Harta milik Maulana Syaikh Zainuddin adalah hibah dari orang tuanya. Dari harta yang dihibahkan tersbebut beliau kembangkan melalui beberapa amal usaha yang kemudian berkembang lebih banyak dari harta yang telah dihibajkan kepada beliau. ${ }^{24}$ Dalam keluarga Maulana Syekh, pembagian warisan dengan pola hibah telah biasa dilakukan dengan pertimbangan kecakapan anak dalam menjaga keutuhan dan kerukunan keluarga. ${ }^{25}$

23 Wawancara dengan Tuan Guru Haji Mustāmin Hafifi, Lc. Pada hari jum’at tanggal 25 Mei 2012 di Gojong Kopang Kabupaten Lombok Tengah

24 Luas tanah sawah desa Majidi lebih dari 230 hektar.Bahkan beliau sendiri tidak mengetahui batas-batas tanahnya. Hanya penyakap (yang mengelola sawah/kebun) yang tahu betul detail jumlah luas tanah Maulana Syaikhlm. Bahkan anak-cucu beliau hari ini pun tidak mengetahui dengan pasti batas tanah sawah dan kebun mereka di desa Majidi.Wawancara dengan Lale Yaqutunnafis, cucu Maulana Syaikh Muhammad Zainuddin Abdul Madjid.

25 Wawancara Dengan TGH. Lalu Gede Wirasakti, Ketua PB. NW, dan sekaligus cucu Maulana 
Walaupun secara usia beliau bukanlah lelaki tertua dalam keluarga. ${ }^{26}$ Dalam hal ini, TGH.Abdul Madjid sudah 'melangkahi' adat yang biasa berlaku dalam masyarakat Sasak, ${ }^{27}$ dan mengutamakan kemaslahatan bagi anak keturunan dan keluarganya dalam pengalihan harta miliknya.

Dari praktek pengalihan harta yang dilakukan Maulana Syaikh Muhammad Zainuddin Abdul Madjid ada beberapa hal yang menjadi catatan penulis sebagai berikut: Pertama, dalam pengalihan harta kepada ahli warisnya beliau memperhatikan aspek keutuhan keluarga. Kedua, dalam pengalihan harta kepada ahli warisnya melalui hibah beliau berupaya membagi sesuai hikmah hukum waris, yaitu distribusi ekonomi secara adil kepada keluarga sesuai dengan peran, fungsi dan tanggung jawab masing-masing.Ketiga, dominasi hukum adat dalam masyarakat Sasak masih sangat kuat, dan posisi perempuan dalam sistem waris adat Sasak sangat marginal.Warisan dengan metode hibah adalah solusi 'perlawanan' kepada sistem waris adat Sasak yang rawan dengan konflik."Jika keluarga dianggap sanggup menjalankan hukum waris Islam, maka beliau memberlakukan hukum waris secara ketat.Namun jika keluarga dirasa belum siap beliau menganjurkan pembagian harta warisan berdasarkan hibah dan lainnya dengan mengikuti pola pembagian hukum waris".

Statemen di atas beliau aplikasikan kepada orang lain, murid dan pengikutnya. Istinbat al-ahkam beliau dalam bidang hukum kewarisan sangat saklek dan tidak berani menyalahi hukum al-Qur'ān, hadìis, dan ijmă', namun pada level tațbì (praktis) beliau mempunyai banyak pertimbangan, sesuai dengan kesiapan mukallaf/masyarakat dalam menjalani hukum tersebut.

Murid dan pengikut Maulana Syekh melakukan pembagian waris dengan berbagai pola. Sebagian pembagian waris itu atas perintah langsung Maulana Syekh kepada yang bersangkutan, dan sebagian lainnya atas dasar tradisi yang diberikan Maulana Syekh kepada muridnya di tempat tertentu, dan jama'ah yang ada di tempat itu meneruskan apa

Syaikh Zainuddin Abdul Madjid, tanggal 23 Mei 2016. Mei 2016.

26 Wawancara Dengan TGH.Lalu Gede Wirasakti, Ketua Dewan Musytasyar PBNW, tanggal 23

27 Metode pembagian waris adat Sasak telah diuraikan sebelumnya dalam bab yang sama. 
yang diperintahkan Maulana Syekh kepada muridnya.

Ragam pola/variasi pembagian warisan sebagaimana dimaksud di atas adalah sebagai berikut :

a. Pola Kewarisan. TGH. Fathurrahman asal Batukliang Lombok Tengah adalah murid Maulana Syekh yang mendapat perintah langsung untuk membagikan warisan sesuai dengan fikih Islam, dan yang tertulis dalam tuhlfat al-ampenāniyyah. ${ }^{28}$ Masyarakat yang mengaji/berguru dari TGH. Fathurrahman lebih banyak mengaplikasikan sistem hukum waris Islam. Sahabudin Al-Ansory, ${ }^{29}$ Zaenal Muttaqien, ${ }^{30}$ Nahriwati, ${ }^{31}$ Faridatul Jannah, ${ }^{32}$ TGH. Mansub Amri, ${ }^{33}$ TGH. Mansyur Rajab, ${ }^{34}$ dan lain-lain menyampaikan hal yang sama.

b. Pola Hibah. Seorang tuan guru muda asal Lombok Tengah pada tahun 1995, beliau menceritakan kondisi keluarganya kepada beliau atas desakan beliau sendiri. Pada saat itu tuan guru muda ini belum memiliki rumah sendiri atas nama dirinya. Atas desakan beliau inilah tuan guru muda itu bercerita tentang hal-ihwal kondisi keluarganya. Berbasis cerita itu kemudian Maulana Syaikh meminta tuan guru muda itu agar orang tuanya membagikan harta yang khusus untuk dirinya dalam bentuk hibah. "Jika orang tuamu tidak mau memberikan hibah tanah miliknya untuk kamu, maka saya akan membangun rumah untukmu di Pancor" ${ }^{\prime 35}$, demikian kata beliau mengakhiri pertemuan dengan tuan guru muda itu. Namun tuan guru muda ini tidak berani menyampaikan langsung amanah Maulana Syaikh kepada orang tuanya. Akhirnya Maulana Syaikh sendiri yang menyampaikan hal yang terkait dengan tuan guru muda tadi kepada orang tuanya. Kalimat yang samapun disampaikan Maulana Syaikh kepada orang tua tuan guru muda itu, "Jika kamu tidak mau memberikan hibah tanah atas nama

28 Wawancara dengan TGH.Fathurrahman, tanggal Juli 2017.

29 Wawancara dengan sahabudin, di Lendang Are, tanggal 30 Juli 2016.

30 Wawancara dengan Zaenal Muttaqien, di Lendang Are, tanggal 31 Juli 2016.

31 Wawancara dengan Nahriwati, di Dames, tanggal 31 Juli 2016

32 Wawancara dengan Faridatul Jannah, di Penujak, tanggal 31 Juli 2016

33 Wawancara dengan Nani Juliarti, dan Siti Umrah Amrillah, diMataram, tanggal 31 Juli 2016

34 Wawancara dengan TGH.Masyhur Rajab, di Sulaga, tanggal 31 Juli 2016

35 Wawancara dengan TGH.Munir, tanggal 7 Februari 2016. 
anakmu ini, maka saya akan membangun rumah untuknya di Pancor". ${ }^{36}$ Dengan ketaatan yang penuh orang tua tuan guru muda itu menyetujui apa yang dikatakan Maulana Syaikh. Tuan guru muda tadi mendapatkan hibah dari orang tuanya berupa tanah dan bangunan, yang sekarang ini telah berkembang menjadi madrasah dan pondok pesantren dengan jumlah santri ribuan orang. ${ }^{37}$ Keterangan yang sama juga didapat dari TGH. Anas Hasyri, ${ }^{38}$ Muhammad Hafizuddin,,${ }^{39}$ Umrah Amrillah, Bahtiar, ${ }^{40} \mathrm{TGH}$. Mugni, ${ }^{41}$ TGH. Muhammad Taisir Kholidy, ${ }^{42}$ dan lain-lain.

c. Pola Wasiat. Yang mendapatkan jawaban atas pola pembagian warisan dengan wasiat adalah TGH. Muhamad Amin. Itu pun disampaikan dalam sebuah pengajian umum yang dilakukan di desa Aikmual. TGH. Amin adalah satu-satunya yang diminta untuk menyelesaikan kasus dengan pola wasiat ini. Selebihnya, praktek wasiat ini merujuk pada TGH. Amin sebagai penerima langsung untuk melaksanakan pembagian warisan dengan pola wasiat. TGH Mansyur Rajab, ${ }^{43}$ TGH Luqmanul Hakim, ${ }^{44}$ TGH. Khairi, ${ }^{45}$ Lalu Amrun, ${ }^{46}$ TGH Khotibuddin, ${ }^{47}$ dan beberapa orang lainnya menjelaskan bahwa pembagian warisan di tempat mereka dengan menggunakan pola wasiat.

\section{d. Pola Pembagian Hukum Waris mengikuti Sistem Hukum Waris} Adat. Sebagai pribadi yang menjadi bagian dari adat masyarakat Sasak, praktek pembagian waris oleh Maulana Syekh juga mempertimbangkan aspek hukum adat. Oleh karenanya, ada beberapa murid beliau yang diperintahkan untuk menyelesaikan pemba-

36 Wawancara dengan TGH.Munir, tanggal 7 Februari 2016.

37 Wawancara dengan pelaku langsung dalam kasus ini (tuan guru muda) yang dalam penelitian ini tidak ingin disebutkan namanya. Beliau hari ini adalah pimpinan salah satu pondok di bawah naungan NW di Lombok Tengah.

38 Wawancara dengan TGH. Anas Hasyri, tanggal 6 Agustus 2017.

39 Wawancara dengan Muh. Hafizudin, di Mapong, tanggal 31 Juli 2016

40 Wawancara dengan Bahtiar, di Jerowaru, tanggal 31 Juli 2016

41 Wawancara dengan TGH. Mugni Sn, di Aik Lomak, tanggal 1 Agustus 2016

42 Wawancara dengan TGH. Muhammad Taisir Kholidy di Pengenem,tanggal 1 Agustus 2016

43 Wawancara dengan TGH. Mashur Rajab, di Aik Mual, tanggal 31 Juli 2016

44 Wawancara dengan TGH. Lukmanul Hakim, di Anjani, tanggal 1 Agustus 2016

45 Wawancara dengan TGH. Khairi, di Suralaga, tanggal 2 Agustus 2016

46 Wawancara dengan Lalu Amrun, di Sekotong, tanggal 31 Juli 2016

47 Wawancara dengan TGH. Khotibudin, di Repok Oak, tanggal 2 Agustus 2016 
gian waris dengan hukum adat. Muh. Hamdani, ${ }^{48}$ Ruslan, ${ }^{49}$ Fatihi, ${ }^{50}$ Martini, ${ }^{51}$ Ekandi, ${ }^{52}$ TGH. Jalaludin Assain, ${ }^{53}$ Kamah Yudiarto, dan lainnya menjelaskan hal yang sama.

\section{KESIMPULAN}

Pola bayāni dalam istinbāt $\}$ al-ahkām adalah untuk merekonstruksi kondisi ideal masyarakat berbasis pada teks suci. Keberlakuan teks suci itu terkadang, dan seringkali terbentur oleh realitas yang belum siap untuk mengaplikasikan ketentuan teks.Pilihannya adalah dialog, karena hakekat hukum Islam adalah 'menaungi' setiap kebutuhan hamba di bawah kemaslahatan. Maulana Syekh Zaenuddin, walau sangat idealis dalam tataran bahasa tulis, namun secara praktis beliau mendialogkan idealisme teks dengan realitas konteks. Upaya ini adalah untuk menghindari konflik dalam proses pembagian warisan. Substansi warisan adalah pengalihan harta, dan dalam proses pengalihan harta itu harus menghindari kemungkinan terjadinya konflik, dan sekecil apapun konflik itu harus diperhitungkan.

Maulana Syekh Zaenuddin sebagai seorang tokoh perubahan masyarakat Lombok, memiliki pengaruh yang kuat dalam bidang social, budaya, politik, dan agama.Beliau adalah 'referensi' dan dijadikan panutan praktis kegamaan masyarakat.dalam bidang huukm waris, pengaruh beliau bagi pengikutnya dapat dipetakan sebagai berikut: 1). Pembagian warisan dilakukan sesuai dengan hukum waris yang tertulis dalam kitab Tuhfah alampenāniyyah. 2). Pembagian warisan dilakukan sesuai dengan hukum waris, namun pembagiannya dilakukan ketika masih hidup. 3). Sebagian harta dihibahkan terlebih dahulu, dan sisa dari harta itulah yang dibagikan sesuai dengan sistem waris Islam. 4). Pembagian warisan dilakukan dilakukan dengan metode hibah yang didasarkan perdamaian/kesepakatan antar anggota keluarga. 5). Pembagian warisan dilakukan melalui wasiat. Namun pada intinya, ragam model pembagian di atas adalah upaya untuk mengalihkan

\footnotetext{
48 Wawancara dengan Muh. Hamdani, di Selaparang, tanggal 02 Agustus 2016

49 Wawancara dengan Ruslan, di Tibu Tangkok, tanggal 31 Juli 2016

50 Wawancara dengan Fatihi, di Dasan Baru, tanggal 31 Juli 2016

51 Wawancara dengan Martini, di Mataram, tanggal 31 Juli 2016

52 Wawancara dengan Hj. Ekandi, di Mataram, tanggal 31 Juli 2016

53 Wawancara dengan TGH. Jalaludin Asyain, di Selanglet, tanggal 31 Juli 2016
} 
harta kekayaan tanpa ada konflik dalam, dan antar anggota keluarga.Konsep untuk menghindari konflik dalam pengalihan harta ini adalah maslahat.

\section{DAFTAR PUSTAKA}

Abdullah, Amin, 2000. Antologi Studi Islam: Teori dan Metodologi, Yogyakarta: Sunan Kalijaga Press

Ahmad Fedyani Saifuddin, 2006. Antropologi Kontemporer: Suatu Pengantar

Kritis Mengenai Paradigma, Jakarta: Kencana Prenada

Amidi, al-, 1981. al-Iḥkām fì Ușūl a-Aḥkām, Beirut: Dar al-Fikr.

Ali, Muhammad Daud, 2007, Hukum Islam, Jakarta: Raja Grafindo

Asyur, Muhammad Tahir ibn, 1999. Al-Maqashid Al-Syari'ah al-Islāmiyyah,

Malaysia: Darul Fajar.

Auda, Jasser, 2007. Figh Al-Maqashid; Ināt ah al-Aḥkām al-Syar'iyah bi AlMaqashidihā (Cet. III) London: al-Ma'had al-'Alami li al-Fikr al-Islami. , 2007. Al-Maqashid Al-Syari'ah'Inda al-Syaikh al-Qaradawi, Qatar 2008. Al-Maqashid Al-Syari'ah: Dalì li al-Mubtadi'in, London: alMa'had al-'Alami li al-Fikr al-Islami.

Azizy, A. Qodri A., 2004. Eklektisme Hukum Nasional: Kompetisi Antara Hukum Islam dan Hukum Umum, Yogyakarta: Gama Media , 2003. Pengembangan Ilmu-mu keislaman, Jakarta: Direktorat Perguruan Tinggi Agama Islam DEPAG RI.

Azra, Azy'umar di, 1999. Jaringan Ulama, Jakarta: Mizan.

Babbie, Earl, 1998. The Practice of Sosial research, Belmont: Wadsworth Publishing Company.

Baidawi, Ibn 'umar , al-, Minhāj al-Ushūl ilā 'Ilm al-Ushūl, Beirut: Muassasah al-Risalah.

Baihaqi., Ahmad Ibn al-Husain, al-, 2003. al-sunan al-Kubro, Beirut: Dar alKutb al-Ilmiyah.

Baharuddin, 2012. Nahdlatul Wathan \& Perubahan Sosial, Yogyakarta:Genta Press.

Bakri, Asafri Jaya,1996. Maqashid Syari'ah menurut Al-Syatibi, Jakarta: PT Raja Grafindo Persada.

1996. Konsep Maqshid Syari'ah Menurut al-Syathibi, Jakarta: Raja Grafindo Persada. 
Basyir, Azhar, 2000. Pokok pokok Persoalan Filsafat Hukum Islam, Yogyakarta: UII Press.

Bek, Muhammad Khudori, 2007. Ushul Figh, terjemahan Fais Al-Muttaqien, Jakarta: Pustaka Amani

Budianti, Erni, Islam Sasak, Yogyakarta: LkiS Pelangi Aksara.

Buti, Muhammad Sa'id Ramadan, al-, 2005. dawābiț al-Mașlaḥah Fì Al-Syari'ah al-Islämiyyah, Damakus: Dar al-Fikr 2009. al-Qadayāal-Fiqhiyyah al-Mu'āșirah, Damaskus: Dar al-Farabi.

Bukhari., Abu Abdillah Muhammad Ibn Isma'il, al-,al-jami'ussholihin, Damaskus: Dar Turuq al-Najah.

Coulson, Noel J., 1964. A History of Islamic Law, Edinburgh: Edinburgh University Press

Daud, Imam Abu, 1422 H. Sunan Abu Daud, Damaskus: Dar Turuq al-Najah\}, 1952. Sunan Abu Dawud, Mesir: Musthaf al-Bab al-Halaby.

Daulibi, Muhammad Ma'ruf, al-, 1965. Al-Madkhal ila 'Ilm Ușūl al-Fiqh, T.t.p.: Dar al-Kitab al-jadīd.

Djamil, Fathurahman, 1995. Metode Ijtihād Majelis Tarjih Muhammadiyah, Jakarta: Logos

Fathurrahman, 1975. ilmu waris, Bandung: al-ma'arif.

Fuad, Muhammad 'Abd al-Ba>qi, 1996. al-Mufahras li Alfäż al-Qur'ān alKarìm, Kairo: Dar al-Hadīs.

George, Ritzer, 1998. Sosiologi Ilmu Pengetahuan Berparadigma Ganda, (terj), Jakarta: CV Rajawali.

Giddens, Anthony, 2003. The Contitution of Society, terj. Adi Loka Sujono, Pasuruan: Pedati.

Hakim, Abu Abdillah Muhammad, al-,1990. Al-Mustadrak 'alā al-ṣahīhain, Beirut: Dar al-Kutb al-'ilmiyah.

Hasan, A., 1996.Al-Faraidh, Jakarta: Pustaka progresif.

Hassan, Husain Hamid, 1971. Nażariyyāt al-Mașlahat fi al-Fiqh al-Islāmy, Kairo: Dar al-Nahḍah al-'Arabiyah.

Hazairin, 1964. Hukum Kewarisan Menurut Qur'an dan Hadīs, Jakarta: Tintamas

Hazm, Ibn, al-Iḥkām fì Uìūl al-Aḥkām, juz VIII, Beirut: Dar A faq al-jadīdah, t.t. 
Hidayat, Qamaruddin, 1993. Memahami Bahasa Agama, Bandung: Mizan Salim, HS, Erlies Septiana Nurbani, 2013, Penerapan Teori Hukum pada Penelitian Tesis dan Disertasi, Jakarta: Raja Gravindo

Jalil, Basiq A., 2010. Ilmu Ushul Figh, Jakarta: Kencana

Jamaluddin,Sejarah Sosial Islam Abad XVIII-XIX', 2004, Tesis, Jakarta: SPs UIN Jakarta.

Jauhar, Ahmadal-Mursi Husain, 2009.Maqashid al-Syari'ah fi al-Islam, terj. Khikmawati,Jakarta: AMZAH.

Jauziyyah, Ibn Al-Qayyim, al-, 1973.I'lam Al-Muwaqqa'in, Bairut: Dar al-Jael 1977. I'lâm al-Muwaqqi'în 'an Rabb al-'âlamin, Beirut, Dâr al-Fikr.

Kamali, Mohammad Hashim,1996. Prinsip dan Teori-teori Hukum Islam, terj. Noorhaidi, Yogyakarta: Pustaka Pelajar.

Khallaf,Abd al-Wahhab, 1972. Mașādir al-Tasyrḍ' al-Islāmy Fìmā lā nașșa fỉhi, Kuwait: Dar al-Qalam ,1978. 'Ilm Ușūl al-Fiqh, Kairo Dar al-Qalam. , 1979.Mașādir al-Tasyrī' al-Islaāmi Fī mā lā nașșa Fīh, Kuwait: Dar al-Qalam.

Khatib, Abdul Karim, al-, 2005, IjtihādMenggerakkan Potensi Dinamis Hukum Islam, Jakarta: Gema Media Pratama.

Kottak, Conrad P., 1987, Anthropology: The Exploration of Human Diversity, New York : Random Hous.

Lombok Kingdom' http://melayuonline.com/eng/history/dig/307/lombok-kingdom, diunduh tanggal 27 April 2017.

Madjid, Muhammad Zainuddin Abdul, 1978, Al-Tuhfah al-Anfananiyyah syarh Al-Nahdlat al-Zainiyah, (Pancor: Pondok Pesantren Darun Nahdlatain/

Mardani, 2013, Ushul Figh, Jakarta: Raja Grafindo,

Mardani, 2013, Ushul Fiqh, Jakarta: Rajawali

Masnun, 2010, Maulana Syaikh TGKH. Muhammad Zainuddin Abdul Madjid Gagasan dan Gerakan Pembaharuan Islam Di Nusa Tenggara Barat, Disertasi Doktor, Yogyakarta: UIN Sunan Kalijaga Yogyakarta.

Meloeng, J, Lexy, 2005, Metode Penelitian Kualitatif, Bandung: PT. Remaja Rosda Karya.

Naim, Abdullah Ahmad, an-, 1997. Dekonstruksi Syariah, alih Bahasa Ahmad 
Suaedi, Yogyakarta: LKiS

Noor, Muhammad dkk., 2004, Visi Kebangsaan Religius; Refleksi Pemikiran dan Perjuangan Tuan Guru Kyai Haji Muhammad Zainuddin Abdul Madjid 19071997 Jakarta: PT. Logos Wacana Ilmu.

Mubarak, Jaih, 2002,Modifikasi Hukum Islam Studi tentang Qawl Qadim dan Qawl Jadid,Jakarta: Raja Grafindo.

Muhibbin, Moh., Abdul Wahid, 2009, Hukum kewarisan Islam, Sebagai Pembaruan Hukum Positif di Indonesia, Jakarta: Sinar Grafika,

Muslim, t.t. Shohih Muslim, Beirut Dar ihya' al-Turat al-Araby.

Musthafa, Ibrahim, et.all, Mu jam al-Wasit, Kairo: Majma' al-Lugah al'Arabiyyah.

Nafis Muhammad Wahyuni, dkk,1995, Kontekstualisasi Ajaran Islam; 70 Tahun Prof. Dr. H. Munawir Sjadzali, Jakarta: Paramadina,

Nahdi, Khirjan, 2009, Nahdlatul Wathan dan Peran Modal Studi Etnografi- Historis Modal Spiritual \& Sosiokultural, Yogyakarta:Genta Press.

Nasution, Harun . 1996, Islam Rasional, Bandung: Mizan. 1995,IjtihädSumber Ketiga Hukum Islam, dalam Haidar Baqir dan Syafiq Basri, Ijtihāddalam Sorotan, Jakarta: Paramadina

Nu'man, Abdul Hayyi, 1999, "Maulana Syaikh Tuan Guru Kyai Haji Muhammad Zainuddin Abdul Madjid", Riwayat Hidup dan Perjuangannya, Lombok Timur: Pengurus Besar Nahdlatul Wathan.

2010, Riwayat Hidup dan Perjuangan Maulana Syaikh TGKH. Muhammad Zainuddin Abdul Madjid, Ilmu Faraidh, Mażhab Ahl-Sunnah Wal Jama'ah, Mataram: Pengurus Besar Nahdlatul Wathan.

Nuruddin, Amir, 1991, Ijtihād'umar Ibn Al-Khaththab, Jakarta: Rajawali Press

Posner, Richard A., 1990, The Problems of Jurispridence, Camridge: Harvard University Press

Praja, Juhaya S., 1991, Hukum Islam di Indonesia, Pemikiran dan Praktik, Bandung: Rosdakarya.

Raisuni, Muhammad, al-, t.t. Al-ijtihādal-Naș al-Maslahah, wa al-Wāqi, Damaskus Dar al-Fikr

Qadi, 'umar Mukhtar, al-, 1993. Ihyā al-Ijtihādfi al-ṣaqāfah al-Islāmiyyah, Kairo: Dar al-Nahḍah al-'Arabiyyah

Qaradawi, Yusuf, al-, 1994. al-Ijtihādal-Mu'āṣir, (Mesir: Dar al-tauzi' wa al- 
Nasyr al-Islāmiyyah,

2006. Dirāsah fi Figh Al-Maqashid Al-Syari'ahBaina al-Al-Maqashid al-Kulliyah wa al-Nuṣuṣ al-Juz'iyyah, Beirut: Dar al-Syuruq.

Rahman, Fazlur, 1994, Membuka Pintu Ijtihād, terjamahan Ahsin Muhammad, Bandung: Pustaka

Rianto, Adi, 2010, Metodologi Penelitian Hukum dan Sosial, Jakarta: Granit

Saadah, Sri Lum'atus, 2012, Peta Pemikiran Figh Progresif, Yogyakarta: Pustaka Pelajar.

Sabiq, Sayyid, 1994. Fiqhussunnah, Saudi Arabia: darul al-Fikr

Sadzali, Munawir, 1994. Reaktualisasi Ajaran Islam, Jakarta: Tintamas

Salahuddin, Muh. 2004, Ijtihād Ekonomi Masyarakat Sasak (Studi tentang Inovasi Produk Jasa Keuangan Di Lembaga Keuangan Mikro Syariah), LP2M, IAIN Mataram.

Sarmadi, Sukris, 1997. Transendensi Keadilan Hukum Waris Islam Transormatif, Jakarta: Raja Grafindo

Shidiq, Sapiudin, 2011. Usul Figh, Jakarta: Kencana.

Sidiq, A. Abdullah, 1984. Hukum Waris Islam, Jakarta: Widjaya

Soejono., Abdurrahman, 2003. Metode Penelitian Hukum, Jakarta: Rineka Cipta

Soekamto, Soerjono., Sri Mamuji, 2010. Penelitian Hukum Normatif Suatu Tinjauan Singkat, Jakarta: Raja Gravindo

Suparman, Eman, 1995, Intisari Hukum Waris Indonesia, Bandung: PT Bandar Maju

Syahrur, Muhammad, 1992. Al-Kitāb wa al-Qur'ān Qirā'ah Mu'așirah, Damaskus: al-Ahab li al-ṭibā'ah li al-Nasyr wa al-tauzī'.

Syarifuddin, Amir, 2004. Hukum Kewarisan Islam, Jakarta: Kencana.

Syatibi, al-, t.t. Ishaq Abu Muhammad, al-Muwāäaqāt fi Ușūl Al-Syari'ah, Kairo: Mustafā Muhammad , al-Muwafaqat fi Ushul al-Syari'ah, Beirut: Dar al-Kutub al-Islamiyah.

Syukur, Asywadie, 1990. Pengantar Ilmu Fikih \& Ushul Fikih, Surabaya: PT. Bina Ilmu.

Syaukani, al-, 1992. Muhammad ibn Ali, Irsyad al-Fuhūl ilā tahqìq al-haq min 'Ilm al-Ușūl, Beirut: Dar al-Fikr

‘Umri, Nadiyah Syarif, al-, 1986.Al-Ijtihād fì al-Islām, Beirūt: Muassasat al- 
Risalah

Usman, Zakiuddin, 2014. Pemikiran Hukum Kewarisan Tuan Guru Haji Muhammad Zainuddin Abdul Madjid (Studi Analitis Terhadap Kitab TuhfahAlAnfanāniyyah,Tesis Pascasaarjana, Yogyakarta:UIN Sunan Kalijaga Yogyakarta.

Wignjosoebroto, Soetandyo, 2002. Hukum Paradigma Metode dan Dinamika Masalahnya, Jakarta: Huma

Wijaya, Hurna, 2015. Figh Nahdhatul Wathan: Telaah Kritis pengamalan Hukum Islam Warga Nahdhatul Wathan, Tesis Pascasarjan, Mataram: IAIN Mataram.

Yahya, Muhtar, 1986. Dasar-Dasar Pembinaan Hukum Figh Islam, al-Ma'arif, Bandung: Al-Ma'arif

Yunus, Mahmud, 1996. Sejarah Pendidikan di Indonesia, Jakarta Hidakarya Agung, 1996

Zahrah, Abu Muhammad, t.t. Ușūl al-Fiqh, Kairo: Dar al-Fikr al-'Arabi Usūul al-Fiqh, Damaskus: Dar el-Fikr al-'Araby.

Zaidan, Abd al-Karim, 1993. Al-Wajiz fì Ușūl al-Fiqh, Kairo: Dar al-Nasyr alIslamiyyah

Zayd, Asrafi Musthafa, 1964.Al-Maslahat fi al-Tasyri' al-Islami, Al-Qahirah: Dar al-Fikr al-Arabi.

Zein, Satria Efendi, 2004, Ushul Figh, II, Jakarta: Kencana

Zuhaily, Wahbah, az-, 1978. al-Wasți Ușülal-Fiqh al-Islāmy, Damaskus, Dar al-Kitab. 